\title{
State of the Elderly in Nigeria: Ethical Dimensions
}

\author{
Nmadu AG, Omole NV, Joshua IA, Muhammad-Idris ZK, Adiri F \\ Department of Community Medicine, College of Medicine, Kaduna State University, Kaduna, Nigeria \\ Corresponding Author: Dr. Awawu Grace Nmadu \\ E-mail: jumainmadu@yahoo.com
}

\begin{abstract}
Ageing populations present a challenge to all regions of the world. This challenge is, however, greatest in Africa which will experience the fastest rate of population ageing than any other region as projected to be in 2050. Nigeria is the most populous country in Africa and the percentage of people aged 60 years and above is predicted to rise from 6.4 million in 2005 to 25.5 million in 2050. The high growth and rapidly increasing numbers of older persons have significant implications for socioeconomic conditions and the challenge is heightened by the concurrent issues of high levels of poverty and the HIV pandemic, which affects the quality of life of millions of people and particularly impacts upon older people. Promotion of the rights of older people as laid down in the Universal Declaration of Human Rights and other declarations have been adopted in many countries of the world including Nigeria, however, the policy and institutional frameworks for tackling the challenges of the ageing population in Nigeria are weak. The traditional support system and family institutions which have been the backbone of support to the elderly in Nigeria are gradually eroding due to modernization and harsh economic conditions. The older persons are faced with many challenges relating to poverty, economic security, access to affordable health care, violence and abuse and integration into social life. This narrative review of literature explores the magnitude of the problem of ageing in Nigeria, factors affecting the situation of older people, the state of social protective policy implementation in Nigeria and the ethical implications.
\end{abstract}

Key words: challenges, elderly, ethical issues, policies, Nigeria.

\section{INTRODUCTION}

Ageing populations present a challenge to all regions of the world, especially in Africa. The population dynamics across all countries in the world have considerably changed over the past century. Contributors to the changing population structure include decreasing rates of mortality, decreasing birth rates and changes in migration trends. These factors can be directly linked to an increasingly ageing population [1]. In Sub-Saharan Africa, it is estimated that the number of elderly persons will rise from about 43 million in 2010 to reach 67 million by 2025 and 163 million by 2050 [2]. There is, however, no general consensus on the age at which a person is regarded as old, although there are commonly used definitions of old age [3]. The World Health Organization (WHO) [4] defines elderly persons as those aged 65 years and older, while the United Nations defines older persons as "those aged 60 years and above" [5]. In Nigeria, anybody that is 60 years and older is considered elderly [6]. The high growth and rapidly increasing numbers of older persons have significant implications for socioeconomic conditions and the challenge is heightened by the concurrent issues of high levels of poverty and the HIV pandemic, which affects the quality of life of millions of people and particularly impact upon older people. Promotion of the rights of older people as laid down in the Universal Declaration of Human Rights [7] and other declarations 
have been adopted in many countries of the world including Nigeria, however, the policy and institutional frameworks for tackling the challenge of ageing in Nigeria are weak [8,9]. The traditional support system and family institution which have been the backbone of support for the elderly in Nigeria are gradually eroding due to modernization and harsh economic conditions [10]. The older persons are faced with many challenges relating to poverty, economic security, access to affordable health care, violence and abuse and integration into social life.

Nigeria is the most populous country in Africa and currently has the highest population of older people in Sub-Saharan Africa8 and recent survey reports and projections indicate a reality not prepared for, of the rising nature of the numbers of the elderly population in Nigeria. Yet there is very little put in place by the government as institutional policies and legislation to cater for the needs of the elderly. There is also a paucity of information on the magnitude of the problems and implications of the population ageing shift in Nigeria. This review explores the challenges of ageing, factors affecting older people, the state of social protective policy implementation in Nigeria and the ethical implications.

\section{METHODOLOGY}

A narrative review of literature using Medline, PubMed, African Journals Online, World Health Organization (WHO) and UN databases was carried out. Search words used included - "elder", "elders" "Elderly", "Aged", "Old", "Older persons", "Challenges", "Policies", "Ethical issues", "Nigeria". We reviewed the reference lists of selected articles for additional articles on the topic. The selected studies primarily reflected the questions being answered in this review. Forty-seven articles published between 1990 and 2018 were selected, 26 of which were included in the review. The review considered original researches, reports and reviews published in English language reporting on people aged 60 years and older. Articles that were not relevant to research objectives of the study and that were not primarily conducted among Nigerians were not included in the review.

Table 1: Description of articles included in the review

\begin{tabular}{|c|c|c|c|}
\hline Author & Title & Type of research & Type of Data \\
\hline $\begin{array}{l}\text { National Population } \\
\text { Commission (NPC) } \\
\text { [Nigeria] and ICF } \\
\text { Macro 2009 }\end{array}$ & $\begin{array}{l}\text { Nigeria Demographic and } \\
\text { Health Survey } 2008 .\end{array}$ & Survey & Quantitative \\
\hline Mudiare 2013 & $\begin{array}{l}\text { Abuse of the aged in } \\
\text { Nigeria: Elders also cry. }\end{array}$ & $\begin{array}{l}\text { Nonsystematic } \\
\text { review }\end{array}$ & Secondary data \\
\hline Ajomale 2007 & $\begin{array}{l}\text { Current State, Social and } \\
\text { Economic Implications of } \\
\text { aging in Nigeria }\end{array}$ & Narrative review & Secondary data \\
\hline Dokpesi AO 2015 & $\begin{array}{l}\text { The future of elderly care } \\
\text { in Nigeria: borrowing a leaf } \\
\text { from a foreign land }\end{array}$ & Literature review & Secondary data \\
\hline $\begin{array}{l}\text { National Population } \\
\text { Commission (NPC) } \\
\text { [Nigeria] and ICF } \\
\text { Macro 2004 } \\
\end{array}$ & $\begin{array}{l}\text { Nigeria Demographic and } \\
\text { Health Survey } 2003\end{array}$ & Survey & Quantitative \\
\hline $\begin{array}{l}\text { Akinyemi Isiugo- } \\
\text { Abanihe } 2014\end{array}$ & $\begin{array}{l}\text { Demographic dynamics } \\
\text { and development in } \\
\text { Nigeria. }\end{array}$ & $\begin{array}{l}\text { Nonsystematic and } \\
\text { desk review of } \\
\text { evidence }\end{array}$ & $\begin{array}{l}\text { Secondary data } \\
\text { sources }\end{array}$ \\
\hline $\begin{array}{l}\text { National Population } \\
\text { Commission (NPC) } \\
\text { [Nigeria] and ICF } \\
\text { Macro 2014 } \\
\end{array}$ & $\begin{array}{l}\text { Nigeria Demographic and } \\
\text { Health Survey } 2013\end{array}$ & Survey & Quantitative \\
\hline
\end{tabular}




\begin{tabular}{|c|c|c|c|}
\hline $\begin{array}{l}\text { Animasahun \& } \\
\text { Chapman } 2017\end{array}$ & $\begin{array}{l}\text { Psychosocial health } \\
\text { challenges of the elderly in } \\
\text { Nigeria: a narrative review. }\end{array}$ & $\begin{array}{l}\text { Nonsystematic } \\
\text { review }\end{array}$ & Secondary data \\
\hline Adeleke 2014 & $\begin{array}{l}\text { Living with modernity: } \\
\text { challenges of ageing in a } \\
\text { transitional Nigerian } \\
\text { Society. }\end{array}$ & Survey & $\begin{array}{l}\text { Quantitative and } \\
\text { Qualitative }\end{array}$ \\
\hline $\begin{array}{l}\text { Shofoyeke \& Amosun } \\
\text { PA } 2014\end{array}$ & $\begin{array}{l}\text { A Survey of Care and } \\
\text { Support for the Elderly } \\
\text { People in Nigeria. }\end{array}$ & Survey & Quantitative \\
\hline Gureje et al. 2008 & $\begin{array}{l}\text { Determinants of quality of } \\
\text { life of elderly Nigerians: } \\
\text { results from the Ibadan } \\
\text { study of ageing. }\end{array}$ & Survey & $\begin{array}{l}\text { Quantitative and } \\
\text { Qualitative }\end{array}$ \\
\hline Uzobo \& Dawodu 2015 & $\begin{array}{l}\text { Ageing and health: A } \\
\text { comparative study of rural } \\
\text { and urbanized status in } \\
\text { Bayelsa State }\end{array}$ & Survey & Quantitative \\
\hline Fajana 2011 & $\begin{array}{l}\text { Decent work deficits in } \\
\text { Nigeria: A constituents' } \\
\text { consensus }\end{array}$ & & \\
\hline Adebowale \& Atte 2012 & $\begin{array}{l}\text { Elderly well-being in a } \\
\text { rural community in North } \\
\text { Central Nigeria, sub- } \\
\text { Saharan Africa. }\end{array}$ & $\begin{array}{l}\text { Descriptive cross- } \\
\text { sectional }\end{array}$ & Quantitative data \\
\hline Iloh et al. 2013 & $\begin{array}{l}\text { Burden of non- } \\
\text { communicable diseases } \\
\text { among geriatric Nigerians } \\
\text { in a rural hospital in } \\
\text { resource-constrained } \\
\text { setting of Eastern Nigeria. }\end{array}$ & $\begin{array}{l}\text { Descriptive } \\
\text { hospital-based } \\
\text { study }\end{array}$ & $\begin{array}{l}\text { Data from clinical } \\
\text { records }\end{array}$ \\
\hline Ekpenyong et al. 2012 & $\begin{array}{l}\text { Double burden, non- } \\
\text { communicable diseases } \\
\text { and risk factors evaluation } \\
\text { in sub-Saharan Africa: The } \\
\text { Nigerian experience. }\end{array}$ & $\begin{array}{l}\text { Cross-sectional } \\
\text { multicenter health } \\
\text { survey }\end{array}$ & Quantitative \\
\hline Karimo et al. 2017 & $\begin{array}{l}\text { Financial Burden } \\
\text { Associated with Ill-Health: } \\
\text { Evidence from the Elderly } \\
\text { Population in Nigeria. }\end{array}$ & $\begin{array}{l}\text { Analysis of data } \\
\text { from a survey }\end{array}$ & $\begin{array}{l}\text { Secondary data } \\
\text { generated from the } \\
\text { Harmonized Nigeria } \\
\text { Living Standard } \\
\text { Survey (HNLSS) }\end{array}$ \\
\hline Eteng \& Utibe 2015 & $\begin{array}{l}\text { The National Health } \\
\text { Insurance Scheme and its } \\
\text { Implication for elderly } \\
\text { Care in Nigeria }\end{array}$ & Narrative review & Secondary data \\
\hline Adedokun 2010 & $\begin{array}{l}\text { Caring for the elderly: } \\
\text { Towards a better } \\
\text { community. }\end{array}$ & $\begin{array}{l}\text { Survey research } \\
\text { design }\end{array}$ & Quantitative \\
\hline Obashoro-John 2011 & $\begin{array}{l}\text { Global Aging Issues: The } \\
\text { Nigerian Situation. }\end{array}$ & Literature review & Secondary data \\
\hline
\end{tabular}




\begin{tabular}{|l|l|l|l|}
\hline Aluko 2007 & $\begin{array}{l}\text { Old Age and Social } \\
\text { Security in Nigeria: The } \\
\text { Challenges of the New } \\
\text { World Order. }\end{array}$ & Survey & Quantitative \\
\hline Akanji et al. 2002 & $\begin{array}{l}\text { Healthcare for older } \\
\text { persons, a country profile }\end{array}$ & Literature review & Secondary data \\
\hline Asagba 2005 & $\begin{array}{l}\text { Research and the } \\
\text { Formulation and } \\
\text { Implementation of Ageing } \\
\text { Policy in Africa: The Case } \\
\text { of Nigeria }\end{array}$ & Narrative review & Secondary data \\
\hline $\begin{array}{l}\text { Gesinde \& Adekeye } \\
\text { Counselling services for } \\
\text { remediating the } \\
\text { biopsychosocial challenges } \\
\text { of the aged in Nigeria }\end{array}$ & $\begin{array}{l}\text { Nhe political economy of } \\
\text { social protection policy } \\
\text { uptake in Nigeria. }\end{array}$ & Report & Secondary data \\
\hline Aiyede et al. 2015 & $\begin{array}{l}\text { Protecting the Rights of } \\
\text { Old People in Nigeria: } \\
\text { Towards a Legal Reform }\end{array}$ & Narrative review & Secondary data \\
\hline Araromi 2015 & $\begin{array}{l}\text { Qualitative and } \\
\text { quantitative }\end{array}$ \\
\hline
\end{tabular}

\section{RESULTS AND DISCUSSION}

\section{Levels and trends in Population Ageing}

In 2017, there were an estimated 962 million people aged 60 or above in the world, comprising 13 percent of the global population [11]. The population aged 60 or above is growing at a rate of about 3 percent per year. It is expected to more than double by 2050 and to more than triple by 2100 , rising from 962 million globally in 2017 to 2.1 billion in 2050 and 3.1 billion in 2100 [11].

Nigeria as the most populous country in Africa currently has the highest number of aged or elderly people in Africa. The total census figures for Nigeria increased from 93 million in 1999 to 140 million in 2006 (growth rate of $3.2 \%$ per annum). It was projected that the population will double in size in just 24 years. 6 Analysis of the 1991 national census predicted that the population of the elderly in Nigeria would reach 5.8 million in 2005, 16 million in 2030 and 47 million by the year 2060 [12]. By 2006, 6.8 million were aged 60 years and above - an increase of 1 million above the 2005 prediction. The population of the aged was also estimated at $4.8 \%$ in 2006 and $5.1 \%$ in 2015 [13]. In Nigeria, life expectancy at birth increased from 40 years in 1970 to 53 years in 2016 and it is projected that life expectancy will increase to 55 years and 63 years in the years 2029 and 2049 respectively [11]. The increase in population of the elderly could be explained by the technological advancements in medicine, and water, hygiene and sanitation measures. Nigeria, like other African nations, reports a significant increase in survival for persons over the age 60 years. 8 This is also not unconnected with the decline in the 4 mortality indicators: neonatal, infant, child, under-five and maternal mortality rates experienced in the country [14]. It is estimated that by the year 2025 the population of Nigerians aged 60 and above will constitute 6 percent of the entire population (Table 1).

Table 2: Projected Population Ageing in Africa, West African and Nigeria (UN 2005) From 2005-2050

\begin{tabular}{|l|l|l|l|l|l|l|}
\hline Region & Population 60 years+ (per cent) & \multicolumn{3}{l|}{ Population 60 years+ (millions) } \\
\hline & 2005 & 2025 & 2050 & 2005 & 2025 & 2050 \\
\hline Africa & 5.2 & 6.4 & 10.0 & 47.4 & 85.5 & 192.9 \\
\hline West Africa & 4.7 & 5.5 & 9.0 & 12.0 & 21.8 & 51.6 \\
\hline Nigeria & 4.9 & 6.0 & 9.9 & 6.4 & 11.5 & 25.5 \\
\hline \multicolumn{7}{|c|}{ Source UN Population Division (2005) }
\end{tabular}




\section{Factors Affecting the Situation of Elderly People in Nigeria}

\section{Limited political will and commitment}

Unfortunately, little has been done to impact on the life situations of older people because ageing problems are seldom considered as important issues in development agenda in many African countries including Nigeria.8 Despite the increase in the proportion of older people in Nigeria, there is a dearth of policies and programs to address the challenges and problems of ageing in the country $[8,15]$. The syndrome of seeing elderly citizen's welfare as the responsibility of the family had made the government of Nigeria do little or nothing to provide for their welfare. In many cases, when they are entitled to a pension, this regrettably is often not paid and when paid, it is frequently not often on time [9]. The majority of elderly Nigerians do not have access to jobs that lead to retirement and attract pensions at old age, hence they are prone to neglect and abandonment in the society. The majority of the ageing population in Nigeria live in rural areas and support themselves by subsistence farming [16]. A large proportion of the aged who live in urban areas the cities are basically self-employed and have to work for their sustenance until they are no longer able to work for their sustenance [17].

\section{Social and economic factors}

Poverty remains a major challenge in Nigeria; more than $60 \%$ of Nigeria's population is estimated to live below the absolute poverty line of $\$ 1$ per day [18]. Poverty is prevalent in the country and elderly persons may be more at risk because they are no longer in the economically active phase of life and the national social security systems do not provide economic buffers in old age [19]. Most of the Nigerian elderly are vulnerable to poverty due to inadequate provision of social services and economic deprivation [20]. Due to poverty and poor infrastructural development, elderly people living in Nigeria not only face lower life expectancies but also live a higher proportion of their lives in poor health. Poverty has prevented many older adults from achieving good well-being and life satisfaction. It is estimated that $70 \%$ of Nigeria's workforce work in the informal sector which lacks any form of social security and protection [21]. Many older adults reach retirement age after a lifetime of poverty and deprivation, poor access to health care and poor dietary intake [22]. These situations leave them with insufficient personal savings to meet their daily needs.

\section{Diminished capacity of the family system to care for the elderly}

Old people in Nigeria generally live in and receive care at their homes or the residence of children or relations [15]. Traditional family support is gradually decreasing given the increasing economic difficulties experienced by families in Nigeria. Increasing levels of unemployment and poverty have made families less able to offer support to older people [17]. Urbanization and migration take young members of the family away and it is increasingly difficult for grown-up children to manage families of their own as well as their aged parents [8]. This put the elderly at risk of neglect whether or not they live alone. This occurs in a context where elderly care in Nigeria is rarely seen in the form of institutionalized centres or private home care as available in industrialized countries.

\section{Health issues of older people and inadequate access to health care}

There is evidence in the reviewed literature on the growing burden of disabilities and chronic diseases among the elderly in Nigeria [23-24]. Old age often comes with health challenges and decreasing functional capacity which usually affects the sense of economic well-being of an individual. According to a study in south-eastern Nigeria, cardiovascular disorders, musculoskeletal disorders, dyspepsia, visual impairment and diabetes mellitus were the commonest non-communicable diseases experienced by geriatric patients [23]. In Nigeria, the current distribution of resources has been heavily skewed towards maternal and child health as well as a biased attention directed to the three big infectious diseases (malaria, tuberculosis and HIV/AIDS), this has left geriatric non-communicable diseases with little attention [23]. All this happens in the background of limited access of the elderly to health care in the country, health care is severely limited both by the paucity of health facilities and manpower and by out-of-pocket 
payment arrangements [22]. In a country with weak primary health care structures, mainly financed by out of pocket payment, old people are limited in accessing and utilizing basic health care services when they do not have the money to pay for such services. It has been reported that more than $50 \%$ of elderly people in Nigeria have unmet healthcare needs because they cannot afford it [25]. In addition, the National Health Insurance Scheme of the federal government has not clearly captured the elderly [26]. This means this group of persons have to pay for their health with out-of-pocket expenses.

\section{Social protection systems}

Nigeria's elderly are disadvantaged regarding social support and the rising population numbers of this group of citizens makes the demand for social support imperative. The majority of the elderly in Nigeria live in the rural areas and are mostly agricultural subsistence farmers, who do not receive pension benefits or social support from the government $[6,27]$. The Contributory Pension Scheme(insurance) in Nigeria does not cover many older persons. This pension scheme is mainly designed for those who are working in the formal sector whereas, the informal sector of the economy represents the major employer of labour and those who, perhaps, are most in need of the limited social security benefits that pension schemes provide, but they are not envisaged in the scheme [28]. The social security arrangement in Nigeria faces many challenges, which include: poor coverage, inadequacy, lack of administrative efficiency and transparency, poor governance and regulation [29]. The pension scheme has been characterized by corruption thereby affecting the elderly access to their money at the appropriate time.

\section{The Nigerian Situation}

The already inadequately funded healthcare system in Nigeria has placed little emphasis on the care of older people because there are "more urgent" health problems, so funding for older people is limited [30]. The health care system in Nigeria spends a small fraction of the budget on treating the elderly and their access to care is limited, access to healthcare is severely limited both by paucity of health facilities and manpower and by out-of-pocket payment arrangement [15].

In 1989, the Nigerian government developed the National Social Development aimed to provide a framework for protecting elderly persons from moral and material neglect and provide public assistance when necessary [15]. Despite adequate provisions, however, there has been no effective execution by any federal agency. This also occurs in the backdrop of Nigeria not yet enacting the National Policy on the care and welfare of older persons. Since March 2003, it has remained in draft form [9]. It has been observed that lawmakers have not been sensitive to the scope, nature and seriousness of older persons' plight in Nigeria; neither are they sensitive to the broad economic and social development implications of leaving these problems unaddressed in the context of rapid population ageing [31].

In Nigeria today, social security policies for the aged are yet to be formulated. The social security system and insurance schemes in Nigeria do not cover many older persons [32]. It covers only the formal sector (public and organized private sector) and is fraught with problems of implementation. There is a failure of the Nigerian federal institutions to regularly disburse pension funds to retirees and provide adequate social services for the aged [9].

In Nigeria, the burden of care squarely rests on family members despite the provisions of the 1999 Constitution, [33] Section 14. 2(b) which states categorically that, "The security and welfare of its people shall be the primary purpose of the government" and in Section 16, sub-section 2(d), which promises, "That suitable and adequate shelter and suitable and adequate food, reasonable national minimum living wage, old age care and pensions and unemployment, sick benefits and welfare of the disabled are provided for all citizens."

Some state government services as well as some religious organizations, non-governmental organizations and community-based organizations, form the bulk of network of support for the elderly in Nigeria in addition to the informal arrangement through the family system.34 Some activities have been implemented - in areas of livelihood support, skills acquisition, capacity building, medical care for the elderly in states in the country like Ekiti and Lagos. There is, however, no regulatory framework for institutionalized elderly care in Nigeria. A few states have 
introduced social assistance for older persons, and these include Ekiti and Anambra States [32]. These states run social welfare packages for senior citizens aimed at taking care of men and women of 65 years and above in the case of Ekiti and 75 years and above in the case of Anambra State [32]. The scheme in Ekiti formally took off in 2011, while that of Anambra took off in 2012.

In Nigeria, institutions such as old people homes for the aged are not very common. There are presently few registered private owned old people's homes in Nigeria [9], showing the limited extent of government participation in the care of older adults.

\section{Ethical dimensions}

From different international and national instruments, the term human rights of older person include the following: the rights to adequate social security, assistance, and protection; right to freedom from discrimination based on age or any other status, in all aspects of life including employment and access to housing, health care and social services; right to good health or healthcare; right to protection from neglect and all types of physical or mental abuse [35]. Other rights include the right to be treated with dignity; the right to full and effective participation in decision - making concerning their well-being; and to full and active participation in all aspects of the political, economic, social and cultural life of society [36].

The Human Rights Council Advisory Committee released a report in January 2010 discussing the global impact of demographic ageing and the increasing number of human rights violations suffered worldwide by the older people in the areas such as physical and moral integrity, susceptibility to poverty, employment, social security and health care [37]. The committee in its report canvassed for the need for a human rights treaty for older people to enhance the visibility of older person in human rights law. It submitted that lack of explicit reference to old people in the general human rights law applicable to everyone is likely to lead to discriminatory attitude and practice to older persons, and as a result, old persons are invisible as a group within the law and are subject to exposure to a myriad of human right violations [37].

Nigeria is yet to adopt the policy that will address the plights of the old people who as a result of their vulnerability are missing out on the enjoyment of basic rights and privileges. The elderly in Nigeria are as a result exposed to discrimination, financial insecurity, social insecurity, various forms of abuse, limited access to health care, and lack of basic human needs - food, shelter and clothing amongst others $[8,15,38]$.

Due to the narrative approach of this study in which the nature of the search method was non systematic, the interpretation of the literature is prone to subjectivity $[39,40,41]$. The authors considered this limitation in their search strategy but were constrained with limited published evidence with explicit methodologies in the literature from Nigeria, they thus gave precedence to the need for an overview of this selected topic. However, this review provides an overview or broad scope of the topic at hand, following guidelines described in previous publications [40,41]. The findings serve as a useful educational tool for this critical public health issue. The review has also helped to identify the gaps within the research area in Nigeria.

\section{CONCLUSION}

Ageing in Nigeria is occurring against the background of socio-economic hardship, widespread poverty, the HIV/AIDS pandemic, the rapid erosion of the traditional extended family structure and lack of political will to address the issues. The lack of reliable national-level data on the situation and needs of older persons have resulted in the low appreciation of ageing and consequently, a lack of development of friendly policies and programs for the aged. Strategies to eliminate discrimination against the elderly and to raise national consciousness of ageing issues should be put in place by government and relevant stakeholders. In addition, the rights due to the old people need to be protected by the State through policy development and legislation as well as implementation. Policies and strategies to address ageing should be included as an integral part of national and sub-national budgets. The need for more current and detailed studies with explicit methodologies on ageing in Nigeria cannot also be overemphasized. 


\section{REFERENCES}

1. Bloom DE, Luca DL. The global demography of ageing: facts, explanations, future. In: Piggott J, Woodland A, editors. Handbook of the economics of population ageing. Oxford: Elsevier; 2016. pp. 3-56.

2. United Nations Department of Economic and Social Affairs (UNDESA). Population Division, World Population Prospects: The 2010 Revision, New York, United Nations, 2011.

3. World Health Organization. Proposed working definition of an older person in Africa for the MDS project [Internet] Geneva: World Health Organization; 2016. Available from: http://www.who.int/healthinfo/survey/ageingdefnolder/en/ [Accessed 20 January 2018].

4. WHO. World Health Organization Health of the Elderly. Tech Rep Series No 779. Geneva, WHO, 1989.

5. United Nations, author. World population ageing 2013 [Internet] New York: United Nations; 2013. Available from: http://www.un.org/en/development/desa/population/publications/pdf/ageing/WorldPopulati onAgeing2013. pdf. [Accessed 20 January 2018].

6. National Population Commission (NPC) [Nigeria] and ICF Macro. Nigeria Demographic and Health Survey 2008. Abuja, Nigeria: National Population Commission and ICF Macro. 2009.

7. The Universal Declaration of Human Rights (UDHR) 1948. Available at http://www.ohchr.org/EN/UDHR/Documents/UDHR_Translations/eng.pdf [Accessed 2 February 2018].

8. Mudiare PE. Abuse of the aged in Nigeria: Elders also cry. Am Int J Contempor Res 2013;3(9):7987.

9. Ajomale OL. Current State, Social and Economic Implications. Summer Newsletter of the Research Committee (RC11) on the Sociology of Ageing of the International Sociological Association (ISA). Oxford Institute of Ageing 2007:15-20.

10. Dokpesi AO. The future of elderly care in Nigeria: borrowing a leaf from a foreign land. Ageing Int 2015;40(2):81-97.

11. United Nations Department of Economic and Social Affairs (UNDESA). Population Division, World Population Prospects: The 2017 Revision, New York, United Nations, 2018.

12. National Population Commission (NPC) [Nigeria] and ICF Macro. Nigeria Demographic and Health Survey 2003. Abuja, Nigeria: National Population Commission and ICF Macro. 2004.

13. Akinyemi AI, Isiugo-Abanihe UC. Demographic dynamics and development in Nigeria. Afr Population Stud 2014;27(2):239.

14. National Population Commission (NPC) [Nigeria] and ICF Macro. Nigeria Demographic and Health Survey 2013. Abuja, Nigeria: National Population Commission and ICF Macro. 2014.

15. Animasahun VJ, Chapman HJ. Psychosocial health challenges of the elderly in Nigeria: a narrative review. Afr Health Sci 2017;17(2):575-83.

16. Adeleke JO. Living with modernity: challenges of ageing in a transitional Nigerian Society. Niger J Appl Behav Sci 2014;2:245-54.

17. Shofoyeke AD, Amosun PA. A Survey of Care and Support for the Elderly People in Nigeria. Mediterr J Soc Sci 2014;5(23):2553.

18. National Bureau of Statistics (NBS). The Nigeria Poverty Profile 2010 Report of the National Bureau of Statistics Harmonized Nigeria Living Standard Survey (HNLSS), 2012.

19. Gureje O, Kola L, Afolabi E, Olley BO. Determinants of quality of life of elderly Nigerians: results from the Ibadan study of ageing. Afr J Med Med Sci 2008;37(3):239-47.

20. Uzobo E, Dawodu OA. Ageing and health: A comparative study of rural and urbanized status in Bayelsa State, Nigeria. Eur Scientific J 2015;11(14):258-73.

21. Fajana, S. Decent work deficits in Nigeria: A constituents' consensus. Geneva. International Labour Office, 2011

22. Adebowale SA, Atte O. Elderly well-being in a rural community in North Central Nigeria, subSaharan Africa. Pub Health Res 2012;2(4):92-101.

23. Iloh GU, Chuku A, Amadi AN. Burden of non-communicable diseases among geriatric Nigerians in a rural hospital in resource-constrained setting of Eastern Nigeria. Sci J Pub Health 2013;1:1416.

24. Ekpenyong CE, Udokang NE, Akpan EE, Samson TK. Double burden, non-communicable diseases and risk factors evaluation in sub-Saharan Africa: The Nigerian experience. Eur J Sustainable Dev 2012;1(2):249-70.

25. Karimo TM, Krokeyi WS, Ekainsai SZ. Financial Burden Associated with Ill-Health: Evidence from the Elderly Population in Nigeria. Equator J Soc Sci Hum Behav 2017;2(1):25-43. 
26. Eteng IE, Utibe EE. The National Health Insurance Scheme and its Implication for elderly Care in Nigeria. Int J Sci Res 2015;(2)4:128-32.

27. Adedokun MO. Caring for the elderly: Towards a better community. Eur J Educ Studies 2010;2(3):284-96

28. Obashoro-John O. Global Aging Issues: The Nigerian Situation. The Journal of Aging in Emerging Economies, 2011 p.62.

29. Aluko Y. Old Age and Social Security in Nigeria: The Challenges of the New World Order. International Journal of Social and Management Sciences 2007;1:73-87.

30. Akanji BO, Ogunniyi A, Baiyewu O. Healthcare for older persons, a country profile: Nigeria. J Am Geriatr Soc 2002;50(7):1289-92.

31. Asagba, A. Research and the Formulation and Implementation of Ageing Policy in Africa: The Case of Nigeria. Generations Review 2005;15(2):39-41.

32. Gesinde AM, Adekeye OA. Counselling services for remediating the biopsychosocial challenges of the aged in Nigeria. J Functional Manage 2011;3(1):89-98.

33. The Federal Republic of Nigeria. Constitution of the Federal Republic of Nigeria 1999. Available at http://www.nigeria-law.org/ConstitutionOfTheFederalRepublicOfNigeria.htm [Assessed 13 January 2017].

34. Aiyede E, Sha P, Haruna B, Olutayo A, Ogunkola E, Best E. The political economy of social protection policy uptake in Nigeria. Partnership for African Social and Governance Research Working Paper 002, 2015 Available at http://www.pasgr.org/wp-content/uploads/2016/08/ThePolitical-Economy-of-Social-Protection-Policy-Uptake-in-Nigeria.pdf [Assessed 24 January 2017].

35. World Health Organization. World report on ageing and health. Geneva: World Health Organization, 2015. Available at http://apps.who.int/iris/bitstream/handle/10665/186463/9789240694811_eng.pdf [Accessed 3 February 2018]

36. Rodriguez-Pinzon D, Martin C. The international human rights status of elderly persons. Am Univ Int Law Rev 2002;18: 915-1008.

37. Human Rights Council, Advisory Committee. The Necessity of Human Rights Approach and Effective United Nations Mechanism for Human Rights of Older People, Working paper, Human Rights Council Advisory Committee, 2010. Available at http://www.ohchr.org/EN/HRBodies/HRC/AdvisoryCommittee/Session4/Pages/Index.aspx [Accessed 5 March 2018].

38. Araromi, M.A. Protecting the Rights of Old People in Nigeria: Towards a Legal Reform. J Law, Policy Globalizn 2015;40:131-43.

39. Grant MJ, Booth A. A typology of reviews: an analysis of 14 review types and associated methodologies. Health Inform Lib J 2009;26(2):91-108.

40. Green BN, Johnson CD, Adams A. Writing narrative literature reviews for peer-reviewed journals: secrets of the trade. J Chiropr Med 2006;5(3):101-17.

41. Ferrari R. Writing narrative style literature reviews. Medical Writing 2015;24(4):230-5.

Acknowledgements - Nil

Source of Funding - Nil

Conflict of Interest $-\mathrm{Nil}$ 